\title{
A Study on the Status, Citation Analysis, and Altmetric Indices of Journals of Golestan University of Medical Sciences
}

\section{Masoud Mohammadi ${ }^{1,2}$, Masoumeh Mirkarimi ${ }^{3}$, Zohereh Paranam ${ }^{3}$, Maryam Banisafar ${ }^{3}$, Mohammad Yadegari ${ }^{4}$, Marzieh Rezanejad ${ }^{3}$, Mahin Tatari ${ }^{3}$, Mohammad Mahboubi*5}

1. Golestan Reserach Center of Gastroenterology and Hepatology, Golestan University of Medical Sciences, Gorgan, Iran.

2. PhD Candidate in Medical Library and Information Science, Tehran University of Medical Sciences, Tehran, Iran.

3. Golestan University of Medical Sciences, Gorgan, Iran.

4. Critical care nursing, Bandar-e gaz Shohada hospital, Golestan University of Medical Sciences, Gorgan, Iran

4. Abadan Faculty of Medical Sciences, Abadan, Iran.

*Correspondence: Abadan Faculty of Medical Sciences, Abadan, Iran. Tel: +98-9126809526.

E-mail: mm59m@yahoo.com

Received July 06, 2019; Accepted December 17, 2019

\section{Abstract}

Background: Journals are regarded as the most important media for transferring knowledge and research results, accordingly their promotion is conditioned by continuous evaluation and improvement of performance. The present study aimed to determine the status, citation analysis, and altmetric indices of journals published by Golestan University of Medical Sciences.

Methods: This cross-sectional study was conducted by a descriptive approach with scientometric and citation analysis methods in 2019. The statistical population consisted of 5 journals of Golestan University of Medical Sciences. Data collection tool was a researcher-made checklist consisting of 28. Altmetric indices of journals were also evaluated. Data was analyzed by descriptive statistics; and the results were presented in diagrams and tables.

Results: All the studied journals had all "publication requirements. Only one journal had the requirement, "at least half of editorial board should be outside of the publication". Moreover, 37 percent of 105 editorial board members in the under examined journals had extra-organizational affiliation and only 8 percent were from abroad. The articles of "Journal of Gorgan University of Medical Sciences" was the most-cited article regarding citation bases.

Conclusions: Journals of Golestan University of Medical Sciences need to revise their structures, especially for editorial board members namely being international, having an 
organizational affiliation outside the university, as well as the presence of editorial board members with further research activity and background.

Keywords: Journals, Citation analysis, Golestan University of Medical Sciences, Scientometrics, Altmetrics

10.29252/jgbfnm.17.1.22

\section{Introduction}

Scientific journals are important tools for development of science in various subjects, such as nursing, midwifery, medicine, and basic sciences that promote and enhance theoretical knowledge and establish links between researchers in different disciplines. Reputable journals are significant tools for any scientific institution for promoting scientific findings. In the field of health, evidence suggest that scientific publications can play valuable roles in the transmission of indigenous knowledge about health and have important effects on the provision, maintenance, and promotion of public health (1).

There is a significant increase in the number of scientific journals due to the emergence of webbased technologies and facilitation of access to Internet resources as well as increased generation of knowledge and the number of scientific texts $(1,2)$. Prior to the emergence of web technology, journals were distributed through services such as mail, email, or other non-web technologies, but the World Wide Web has made it possible to distribute scientific journals globally at the shortest possible time. The presence of scientific journals on the web has had an evolving trend, and thus journals have been introduced only on the early days. Gradually, the lists of content and abstracts became more popular. With the development of technology, full-text publishing on websites became also possible (2). What is noteworthy with these quantitative expansions is the quality of content and professional principles of scientific journals as an index of competitiveness of journals in national and international arenas. Studies indicate that despite the importance of scientific journals, most of them locally have cycles of problems that not only lead to not receiving appropriate articles for publication, but also represent low quality for review, printing and publication of articles (2). Therefore, analysis and evaluation of status of journals are very important to resolve the problems. Content and citation analyses are methods of analysis and evaluation of journals. In this field, quantitative criteria can be obtained for the journals and articles, and necessary tools can be provided for qualitative and quantitative study of journals (3). In line with qualitative and quantitative evaluations of journals, the international presence of 
journals is particularly important as among enormous volumes and variety of scientific publications, only those journals, which meet acceptable standards, have access to the international databases (4). In fact, indexing journals on international scientific bases is particularly important as a major part of a credible scientific production; and the absence of journals in such environments will reduce the possibility of their citation and visibility (5). Databases have specific evaluation criteria for indexing journals, indicating the accuracy and quality of their available records. For instance, the most important criteria for indexing journals in Scopus database are the credibility of the editorial board, editor-in-chief, and evaluation of the number of citations to journal articles. The Web of Science database has mentioned the evaluation of editorial board, the international variety of published articles in journals, and the citation status of journals for indexing as the most important criteria (6).

On the other hand, Altimetry scales which are derived from the social web, are increasingly being advocated and used as primary indices of the impact and usefulness of articles. Generally, alternative scales are called by this name to reflect their distinction from bibliometrics (traditional citation counting systems) and web metrics (measuring web page rank or its impact by analyzing links between web pages). There are various types of data that are collected for research, such as page views articles, storage and bookmarks of document, pdf downloads, tags, likes, or sharing on social networks, storage, and suggestions for blog posts that reflect different dimensions of effect (6).

The Medical Sciences Publications Commission of Ministry of Health has also provided conditions for standardizing the process of publishing scientific journals with regards to its conditions for obtaining a scientific-research rank and preliminary agreement under which domestic journals need to comply with its principles. Therefore, it is necessary to pay attention to national and international standards and requirements for medical journals in the field of medical sciences.

This is also true for journals of Golestan University of Medical Sciences, as well as the content and citation evaluation and examination of Altimetry indices in these journals to identify the current status and also to plan for solving their problems. Therefore, the present study investigated the status and citation analysis of journals of Golestan University of Medical Sciences. 


\section{Methods}

Using the scientometric methods and citation analysis, the present cross-sectional descriptive study investigated the status of Golestan University of Medical Sciences journals that were published in March 2018. In this study, we examined 5 journals, include "Scientific Journal of Gorgan University of Medical Sciences", "Journal of Clinical and Basic Research", "Medical Laboratory Journal", "Jorjani Biomedicine Journal", and "Journal of Research Development in Nursing \& Midwifery". The evaluation of journal was done in three sections.

In the first section, the status of journals was evaluated based on indices of the Medical Sciences Publications Commission. In this section, the research tool was a researcher-made checklist that was prepared first by extracting requirements for publishing medical journals, and subsequently was formulated in accordance with guidelines of medical journals, by referring to website of the Center for Development and Coordination of Scientific Information and Publications of deputy of Research and Technology of the Ministry of Health1. The guidelines included the Rules of Publication of Journals of Medical Science (7), Principles and Procedures for Applying for preliminary agreement (8), New conditions for preliminary agreement and scientific-research rank (9), Guidelines and procedures for applying for scientific-research rank (9), and general approvals of meetings of the Medical Sciences Commission (10). The extracted components were then classified into three categories, compliance with the publication requirements, requirements of specific websites of journals, and composition of authorities of journals in 28 items. The percentage of compliance in each domain was obtained by dividing the number of eligible cases by the total number of items in that component.

The average number of observations and the number of downloads were studied in the second section among Altimetry indices of journals. The findings were obtained from the management sections and websites of journals.

In the third section, all publications of Golestan University of Medical Sciences were cited. To this end, all articles of the reviewed journals were investigated in two citation databases, namely Web of Science and Scopus on April 9, 2019. Searching journals was done in the Scopus database in Web of Science database in "Cited References Search" section. The presented

${ }^{1}$ http://hbi.ir/part2/Default.aspx?templateid=2 
instruction in Table 1 was used to extract cited articles for each journal.

Table 1. Syntaxes of searching journal names to extract the citation information of reviewed journals

\begin{tabular}{|c|c|}
\hline Journal name & Searched formats \\
\hline $\begin{array}{l}\text { Journal of Clinical and } \\
\text { Basic Research }\end{array}$ & "Journal of Clinical and Basic Research" OR "JCBR" \\
\hline $\begin{array}{l}\text { Jorjani Biomedicine } \\
\text { Journal }\end{array}$ & $\begin{array}{c}\text { "Jorjani Biomedicine Journal” OR "Jorjani Biomed J" OR "Hakim Jorjani } \\
\text { Journal” }\end{array}$ \\
\hline $\begin{array}{l}\text { Journal of Research } \\
\text { Development in Nurs- } \\
\text { ing \& Midwifery }\end{array}$ & $\begin{array}{c}\text { "Journal of Research Development in Nursing \& Midwifery" OR "Journal } \\
\text { of Research Development in Nursing and Midwifery" OR "Journal of } \\
\text { BouyehGorgan Faculty of Nursing \& Midwifery" OR "J GorganBouyeh } \\
\text { Faculty Nurs Midwifery" OR "J GorganBouyeh Faculty of Nursing \& } \\
\text { Midwifery" OR "Journal of GorganBouyeh Faculty of Nursing and Mid- } \\
\text { wifery" OR "J GorganBouyehFacNursMidwif" }\end{array}$ \\
\hline $\begin{array}{l}\text { Medical Laboratory } \\
\text { Journal }\end{array}$ & "Medical Laboratory Journal" OR "MLJ" \\
\hline $\begin{array}{l}\text { Journal of Gorgan } \\
\text { University of Medical } \\
\text { Sciences }\end{array}$ & $\begin{array}{l}\text { "Journal of Gorgan University of Medical Sciences" OR "J GorganUniv } \\
\text { Med Sic" OR " Majallah-i Danishgah-i Ulum-i Pizishki-i Gurgan" }\end{array}$ \\
\hline
\end{tabular}

\section{Results}

The results indicated that all the studied journals met the "publication requirements" completely. Furthermore, all journals had the same status with respect to the "requirements of specific websites of journals" and were eligible except for indices of "non-blocking site due to speed of the IP server base", and "ability to download all abstracts of a single copy of journal altogether" (Table 2).

Table 2. Detailed results regarding indexes of 3 studied axes

\begin{tabular}{|c|c|c|c|c|c|c|}
\hline Axis & Index name & 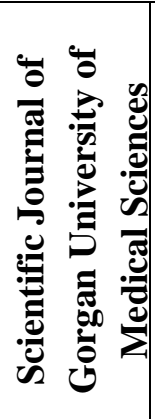 & 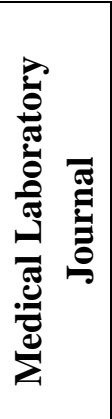 & 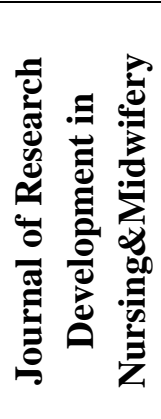 & 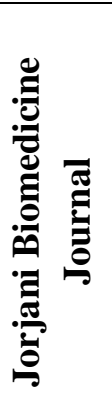 & 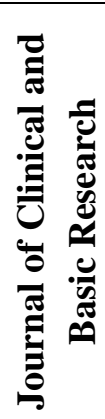 \\
\hline 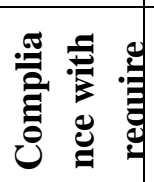 & $\begin{array}{c}\text { License of publication by the } \\
\text { Ministry of Culture and Islamic } \\
\text { Guidance }\end{array}$ & $\checkmark$ & $\checkmark$ & $\checkmark$ & $\checkmark$ & $\checkmark$ \\
\hline
\end{tabular}




\begin{tabular}{|c|c|c|c|c|c|c|}
\hline & $\begin{array}{c}\text { Having the preliminary agreement } \\
\text { of the Medical Sciences } \\
\text { Commission of Iran }\end{array}$ & $\checkmark$ & $\checkmark$ & $\checkmark$ & $\checkmark$ & $\checkmark$ \\
\hline & $\begin{array}{c}\text { Issuance of written command by } \\
\text { the Medical Sciences Publications } \\
\text { Commission }\end{array}$ & $\checkmark$ & $\checkmark$ & $\checkmark$ & $\checkmark$ & $\checkmark$ \\
\hline & Obtaining a publication license & $\checkmark$ & $\checkmark$ & $\checkmark$ & $\checkmark$ & $\checkmark$ \\
\hline & $\begin{array}{c}\text { Letter of announcement of } \\
\text { registered ISSN }\end{array}$ & $\checkmark$ & $\checkmark$ & $\checkmark$ & $\checkmark$ & $\checkmark$ \\
\hline & $\begin{array}{c}\text { Compliance with language of } \\
\text { obtained license }\end{array}$ & $\checkmark$ & $\checkmark$ & $\checkmark$ & $\checkmark$ & $\checkmark$ \\
\hline & Percentage of compatibility & 100 & 100 & 100 & 100 & 100 \\
\hline & $\begin{array}{c}\text { Existence of article abstracts in } \\
\text { XML format }\end{array}$ & $\checkmark$ & $\checkmark$ & $\checkmark$ & $\checkmark$ & $\checkmark$ \\
\hline & Full text of articles in PDF & $\checkmark$ & $\checkmark$ & $\checkmark$ & $\checkmark$ & $\checkmark$ \\
\hline 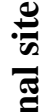 & $\begin{array}{c}\text { No site blocking due to speed of IP } \\
\text { server base }\end{array}$ & $x$ & $x$ & $x$ & $x$ & $x$ \\
\hline 串 & $\begin{array}{l}\text { Inserting date of release of the } \\
\text { latest version clearly and precisely }\end{array}$ & $\checkmark$ & $\checkmark$ & $\checkmark$ & $\checkmark$ & $\checkmark$ \\
\hline 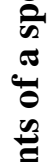 & $\begin{array}{c}\text { Insert a version list page at a } \\
\text { specific address or home page with } \\
\text { a regular pattern }\end{array}$ & $\checkmark$ & $\checkmark$ & $\checkmark$ & $\checkmark$ & $\checkmark$ \\
\hline : & $\begin{array}{l}\text { Article page for each version in the } \\
\text { address of each version with a } \\
\text { regular template }\end{array}$ & $\checkmark$ & $\checkmark$ & $\checkmark$ & $\checkmark$ & $\checkmark$ \\
\hline 递 & $\begin{array}{c}\text { Regular xml output for each article } \\
\text { matching a sample }\end{array}$ & $\checkmark$ & $\checkmark$ & $\checkmark$ & $\checkmark$ & $\checkmark$ \\
\hline ฮै & $\begin{array}{l}\text { Article information in both } \\
\text { languages in the xml file }\end{array}$ & $\checkmark$ & $\checkmark$ & $\checkmark$ & $\checkmark$ & $\checkmark$ \\
\hline & $\begin{array}{c}\text { Publishing each article separately } \\
\text { with a specific address }\end{array}$ & $\checkmark$ & $\checkmark$ & $\checkmark$ & $\checkmark$ & $\checkmark$ \\
\hline
\end{tabular}




\begin{tabular}{|c|c|c|c|c|c|c|}
\hline & $\begin{array}{l}\text { Textual metadata information for } \\
\text { each article (title, authors, } \\
\text { abstracts and keywords) }\end{array}$ & $\checkmark$ & $\checkmark$ & $\checkmark$ & $\checkmark$ & $\checkmark$ \\
\hline & $\begin{array}{c}\text { Existence of PDF files of articles in } \\
\text { a clear address on the article page } \\
\text { or XML output }\end{array}$ & $\checkmark$ & $\checkmark$ & $\checkmark$ & $\checkmark$ & $\checkmark$ \\
\hline & $\begin{array}{l}\text { The possibility of downloading all } \\
\text { abstracts of a version of journal }\end{array}$ & $\checkmark$ & $\checkmark$ & $\checkmark$ & $\checkmark$ & $\checkmark$ \\
\hline & $\begin{array}{l}\text { Having a direct link to editorial } \\
\text { board }\end{array}$ & $\checkmark$ & $\checkmark$ & $\checkmark$ & $\checkmark$ & $\checkmark$ \\
\hline & $\begin{array}{c}\text { Having a direct link to editorial } \\
\text { policies }\end{array}$ & $\checkmark$ & $\checkmark$ & $\checkmark$ & $\checkmark$ & $\checkmark$ \\
\hline & $\begin{array}{l}\text { The possibility of downloading all } \\
\text { abstracts of a single copy of } \\
\text { journal at once }\end{array}$ & $x$ & $x$ & $x$ & $x$ & $x$ \\
\hline & Percentage of compatibility & 86.6 & 86.6 & 86.6 & 86.6 & 86.6 \\
\hline & $\begin{array}{l}\text { At least half of editorial staff are } \\
\text { associate professors. }\end{array}$ & $\checkmark$ & $\checkmark$ & $x$ & $x$ & $\checkmark$ \\
\hline 胥 & $\begin{array}{l}\text { At least half of editorial staff are } \\
\text { from outside the publication. }\end{array}$ & $x$ & $\checkmark$ & $x$ & $x$ & $x$ \\
\hline 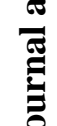 & $\begin{array}{l}\text { Publishing at least } 3 \text { articles in the } \\
\text { last } 3 \text { years by the editorial staff }\end{array}$ & $\checkmark$ & $\checkmark$ & $x$ & $\checkmark$ & $\checkmark$ \\
\hline$\stackrel{0}{0}$ & $\begin{array}{c}\text { Editor-in-chief's degree of at least } \\
\text { the associate professor }\end{array}$ & $\checkmark$ & $\checkmark$ & $x$ & $x$ & $\checkmark$ \\
\hline हैं & $\begin{array}{c}\text { Editor-in-chief's activity in at most } \\
\text { a publication }\end{array}$ & $\checkmark$ & $\checkmark$ & $\checkmark$ & $\checkmark$ & $\checkmark$ \\
\hline & Percentage of compatibility & 80 & 100 & 20 & 40 & 80 \\
\hline & Sum & 88.86 & 95.53 & 68.86 & 75.53 & 88.86 \\
\hline
\end{tabular}

Given the compliance with the requirements of the National Committee for Medical Sciences Journals, the findings indicated that the Medical Laboratory Journal was in compliance with the 
requirements of the National Committee for Medical Sciences Journals; while the Journal of Research Development in Nursing \& Midwifery solely had the "editor-in-chief's activity in at most a journals" index (Table 3 ).

Table 3. Compliance of journal of Golestan University of Medical Sciences with indices of 3 studied axes

\begin{tabular}{|c|c|c|c|c|c|}
\hline Journal name & 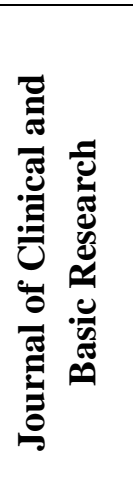 & 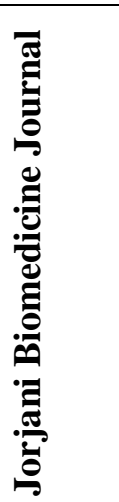 & 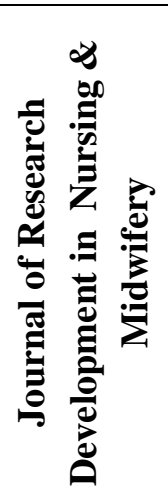 & 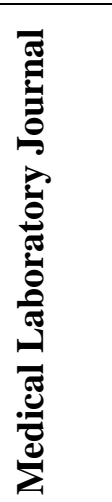 & 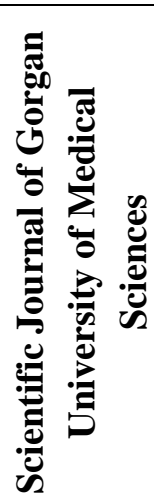 \\
\hline $\begin{array}{l}\text { Requirements for } \\
\text { publication of journals }\end{array}$ & 100 & 100 & 100 & 100 & 100 \\
\hline $\begin{array}{l}\text { Compliance with } \\
\text { requirements of specific } \\
\text { sites of journals }\end{array}$ & 86.6 & 86.6 & 86.6 & 86.6 & 86.6 \\
\hline $\begin{array}{l}\text { Composition of journal } \\
\text { authorities }\end{array}$ & 80 & 40 & 20 & 100 & 80 \\
\hline Sum & 88.86 & 75.53 & 68.86 & 95.53 & 88.86 \\
\hline
\end{tabular}

In the field of affiliation status of editorial staff of journals, the findings indicated that the presence of international researchers in the editorial board composition of Jorjani Biomedicine Journal showed the highest rate of $14 \%$, and the scientific journal of Gorgan University of Medical Sciences with 9 individuals had the maximum number of international editorial members. None of editorial board in Journal of Development Research in Nursing \& Midwifery were international researchers. More than 50 percent of editorial board of all journals were from Golestan University of Medical Sciences. The lowest participation (28\%) of extra-organizational editorial board belonged to Jorjani Biomedicine Journal, and the highest participation (48\%) was related to the Medical Laboratory Journal.

In terms of academic rank of editorial board, $57 \%$ of the editorial board of Scientific Journal of 
Gorgan University of Medical Sciences were full professors, and 78\% of editorial board of Jorjani Biomedicine Journal were assistant professors (Table 4).

Table 4. The Status of journals of Golestan University of Medical Sciences in terms of affiliation and ranks of by editorial board and editor-in-chief

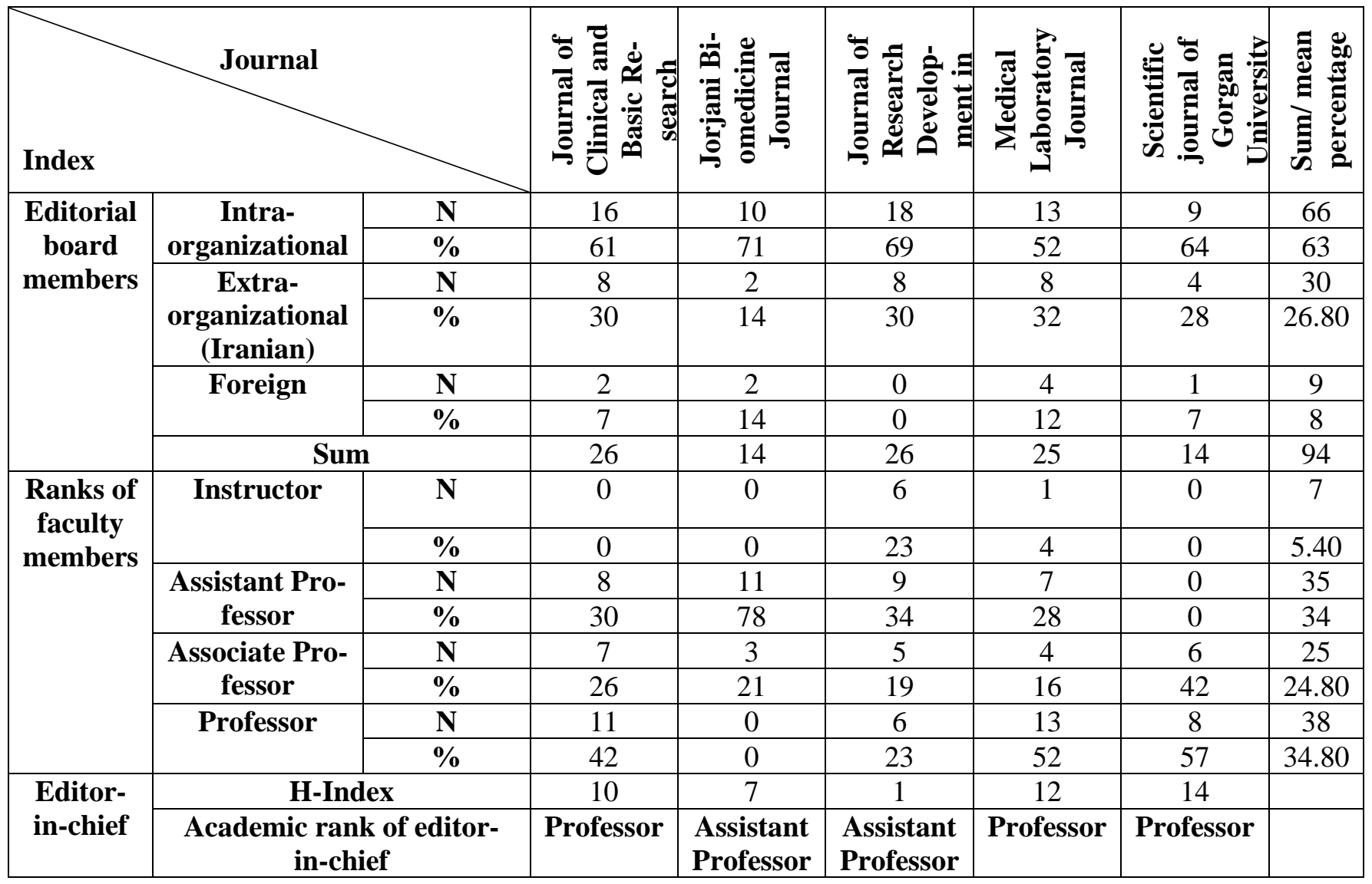

In the field of the condition, "all members should have at least three published articles in domestic journals with scientific-research ranks or reputable foreign journals, which are indexed in journals that are approved by the Journal Commission, in the last three years", the findings indicated that all editorial staff of Jorjani Biomedicine Journal and Scientific Journal of Gorgan University of Medical Sciences had at least 3 articles in accordance with the above mentioned criteria, while $32 \%$ of the Editorial Board members in Medical Laboratory Journal and 34.6 percent of the editorial staff in Journal of Development Research in Nursing \& Midwifery didn`t fulfill the condition of having at least 3 articles in the last 3 years.

In terms of the number of published articles, it was found that the Journal of Gorgan University of Medical Sciences published the highest number of articles $(n=1087)$, with an average of 16 
articles per issue (Table 5).

Table 5. The number of published articles in journals of Golestan University of Medical Sciences until 2019

\begin{tabular}{|c|c|c|c|c|c|}
\hline Index & $\begin{array}{c}\text { Journal of } \\
\text { Clinical } \\
\text { and Basic } \\
\text { Research } \\
\text { (JCBR) }\end{array}$ & $\begin{array}{c}\text { Jorjani Bi- } \\
\text { omedicine } \\
\text { Journal }\end{array}$ & $\begin{array}{c}\text { Journal of } \\
\text { Research De- } \\
\text { velopment in } \\
\text { Nursing \& } \\
\text { Midwifery }\end{array}$ & $\begin{array}{c}\text { Medical } \\
\text { Laboratory } \\
\text { Journal }\end{array}$ & $\begin{array}{c}\text { Scientific journal } \\
\text { of Gorgan Uni- } \\
\text { versity of Medi- } \\
\text { cal Sciences }\end{array}$ \\
\hline $\begin{array}{c}\text { Total number of pub- } \\
\text { lished articles }\end{array}$ & 64 & 115 & 209 & 521 & 1087 \\
\hline $\begin{array}{c}\text { Total number of re- } \\
\text { leased issues }\end{array}$ & 8 & 14 & 21 & 50 & 68 \\
\hline $\begin{array}{c}\text { Mean number of pub- } \\
\text { lished articles per issue }\end{array}$ & 8 & 8.21 & 9.95 & 10.42 & 15.98 \\
\hline
\end{tabular}

The status of authors' contribution to the compilation of articles was another studied component. Based on the obtained findings from reviewing journal articles during 2017 and 2018, it was found that the Journal of Clinical and Basic Research (JCBR) with an average number of authors $(n=4.6)$ had the highest average number of authors, and the articles of other journals had an average number of 3.5 authors (Table 6).

Table 6. The number of authors of published articles in journals of Golestan University of Medical Sciences during 2017 and 2018

\begin{tabular}{|c|c|c|c|c|c|}
\hline Journal & $\begin{array}{c}\text { Journal of } \\
\text { Clinical } \\
\text { and Basic } \\
\text { Research } \\
\text { Index }\end{array}$ & $\begin{array}{c}\text { Jorjani Bi- } \\
\text { omedicine } \\
\text { Journal }\end{array}$ & $\begin{array}{c}\text { Journal of } \\
\text { Research De- } \\
\text { velopment in } \\
\text { Nursing \& } \\
\text { Midwifery }\end{array}$ & $\begin{array}{c}\text { Medical } \\
\text { Laboratory } \\
\text { Journal }\end{array}$ & $\begin{array}{c}\text { Scientific journal } \\
\text { of Gorgan Uni- } \\
\text { versity of Medi- } \\
\text { cal Sciences }\end{array}$ \\
\hline Total number of authors & 294 & 141 & 150 & 254 & 484 \\
\hline $\begin{array}{c}\text { Average number of au- } \\
\text { thors }\end{array}$ & $4.59 \pm 1.88$ & $3.61 \pm 1.44$ & $3.66 \pm 1.37$ & $3.53 \pm 1.3$ & $3.78 \pm 1.56$ \\
\hline
\end{tabular}

Findings indicated that authors of Golestan University of Medical Sciences collaborated internationally with researchers from abroad in only 3 articles of Jorjani Biomedicine Journal. There was no international cooperation in other articles. In terms of the rate of out-of-university authors' cooperation, the results indicated that 17 percent of the authors of Journal of Clinical and Basic Research were affiliated with Golestan University of Medical Sciences. Furthermore, 
$12.92 \%$ of its articles belonged to the first author with affiliation of Golestan University of Medical Sciences, while $15.64 \%$ of articles had corresponding authors affiliated with Golestan University of Medical Sciences. In other words, the journal had the lowest author's participation from outside of the university with regards to authoring articles. Moreover, 6.29\% of articles of Medical Laboratory Journal exclusively had authors with affiliation to Golestan University of Medical Sciences, and $4.33 \%$ of articles had corresponding authors who were affiliated to Golestan University of Medical Sciences with the highest number of authors from the outside of journal publishing organization (Table 7).

Table 7. The participation of authors with affiliation of Golestan University of Medical Sciences in published articles of studied journals, during 2017 and 2018

\begin{tabular}{|c|c|c|c|c|c|c|c|}
\hline \multicolumn{2}{|l|}{ Journal } & 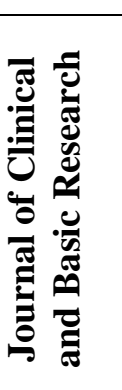 & 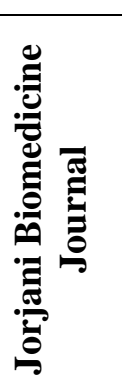 & 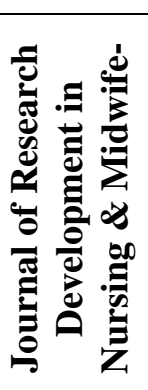 & 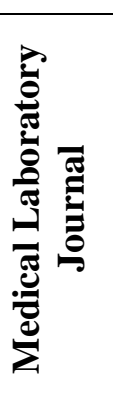 & 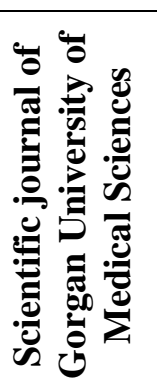 & 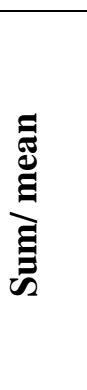 \\
\hline \multirow{2}{*}{$\begin{array}{l}\text { Articles with authors with } \\
\text { affiliation to Golestan Uni- } \\
\text { versity of Medical Sciences }\end{array}$} & Number & 50 & 11 & 14 & 16 & 34 & 125 \\
\hline & percentage & 17 & 7.80 & 9.33 & 6.29 & 7.02 & 9.48 \\
\hline \multirow{2}{*}{$\begin{array}{c}\text { Articles with first authors } \\
\text { with affiliation to Golestan } \\
\text { University of Medical Sci- } \\
\text { ences } \\
\end{array}$} & Number & 38 & 7 & 13 & 14 & 25 & 97 \\
\hline & percentage & 12.92 & 4.96 & 8.66 & 5.51 & 5.16 & 7.42 \\
\hline \multirow{2}{*}{$\begin{array}{c}\text { Articles with corresponding } \\
\text { authors with affiliation to } \\
\text { Golestan University of Medi- } \\
\text { cal Sciences }\end{array}$} & Number & 46 & 8 & 12 & 11 & 28 & 105 \\
\hline & percentage & 15.64 & 5.67 & 8 & 4.33 & 5.75 & 7.87 \\
\hline
\end{tabular}

The analysis of two important Altimetry indexes of journals indicated that the highest number of abstracts was related to articles of Journal of Development Research in Nursing \& Midwifery and Medical Laboratory Journal respectively, while the least number of abstracts belonged to Jorjani Biomedicine Journal. Regarding downloading the article text, the Medical Laboratory Journal had the highest number of downloads, whereas the Jorjani Biomedicine Journal had the lowest number (Table 8). 
Table 8. Altmetric indexes of Journals of Golestan University of Medical Sciences (2017 and 2018)

\begin{tabular}{|c|c|c|c|c|c|c|}
\hline Journal & 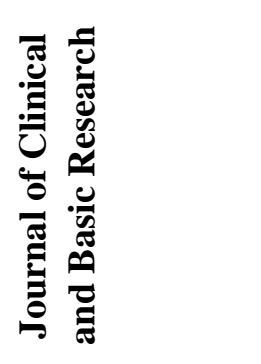 & 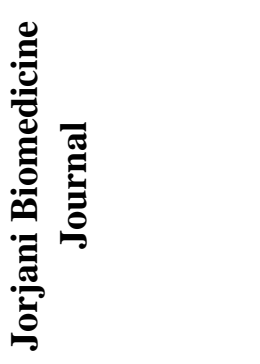 & 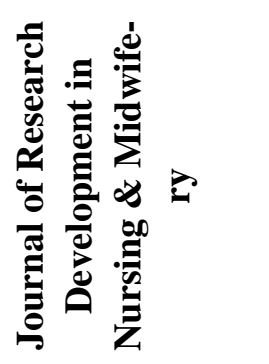 & 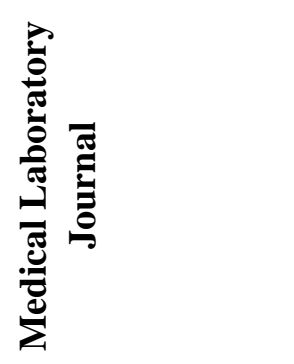 & 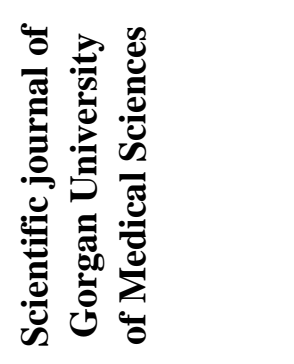 & 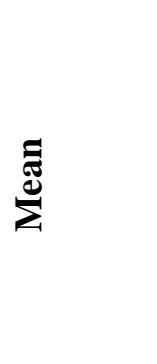 \\
\hline $\begin{array}{l}\text { Mean num- } \\
\text { ber of ob- } \\
\text { servation }\end{array}$ & $607.73 \pm 413.99$ & $823.92 \pm 711.47$ & $8290.1 \pm 3682.48$ & $5716.43 \pm 2887.44$ & $3443.33 \pm 1453.43$ & 3776.302 \\
\hline $\begin{array}{l}\text { Mean num- } \\
\text { ber of down- } \\
\text { loads }\end{array}$ & $295.78 \pm 279.99$ & $347.89 \pm 374.81$ & $534.02 \pm 282$ & $734.44 \pm 258.81$ & $436.95 \pm 255.33$ & 469.816 \\
\hline
\end{tabular}

Results of the citation analysis indicated that "Scientific Journal of Gorgan University of Medical Sciences" with a total of 915 citations in two citation databases, Web of Science and Scopus, received the most citations, indicating that each of its articles received 0.56 citations on average in the citation database Scopus. Furthermore, the Jorjani Biomedicine Journal with only 8 citations and a mean of 0.03 citations per article received the lowest number of citations (Table 9).

Table 9. Citation rate of published articles in journals of Golestan University of Medical Sciences in two databases, Web of Science and Scopus

\begin{tabular}{|c|c|c|c|c|c|c|c|c|c|c|}
\hline \multirow[t]{2}{*}{ Journal/ Index } & \multicolumn{2}{|c|}{$\begin{array}{c}\text { Scientific } \\
\text { journal of } \\
\text { Gorgan } \\
\text { University of } \\
\text { Medical } \\
\text { Sciences }\end{array}$} & \multicolumn{2}{|c|}{$\begin{array}{c}\text { Journal of } \\
\text { Clinical and } \\
\text { Basic Research }\end{array}$} & \multicolumn{2}{|c|}{$\begin{array}{l}\text { Medical } \\
\text { Laboratory } \\
\text { Journal }\end{array}$} & \multicolumn{2}{|c|}{$\begin{array}{c}\text { Jorjani } \\
\text { Biomedicine } \\
\text { Journal }\end{array}$} & \multicolumn{2}{|c|}{$\begin{array}{c}\text { Journal of } \\
\text { Research } \\
\text { Development in } \\
\text { Nursing \& } \\
\text { Midwifery }\end{array}$} \\
\hline & WOS & Scopus & $\begin{array}{c}\text { WO } \\
\text { So }\end{array}$ & Scopus & WOS & Scopus & WOS & Scopus & WOS & Scopus \\
\hline Received citations & 297 & 618 & 2 & 4 & 36 & 53 & 4 & 4 & 82 & 132 \\
\hline Citations per article & 0.27 & 0.56 & 0.03 & 0.06 & 0.06 & 0.1 & 0.03 & 0.03 & 0.39 & 0.63 \\
\hline
\end{tabular}

The citation process of journals on the Web of Science database has indicated a significant jump and growth in the citation of articles in the journals since 2015. The same citation process exists 
in the Scopus database, but with a slower slope than Web of Science (Figure 1 and 2).

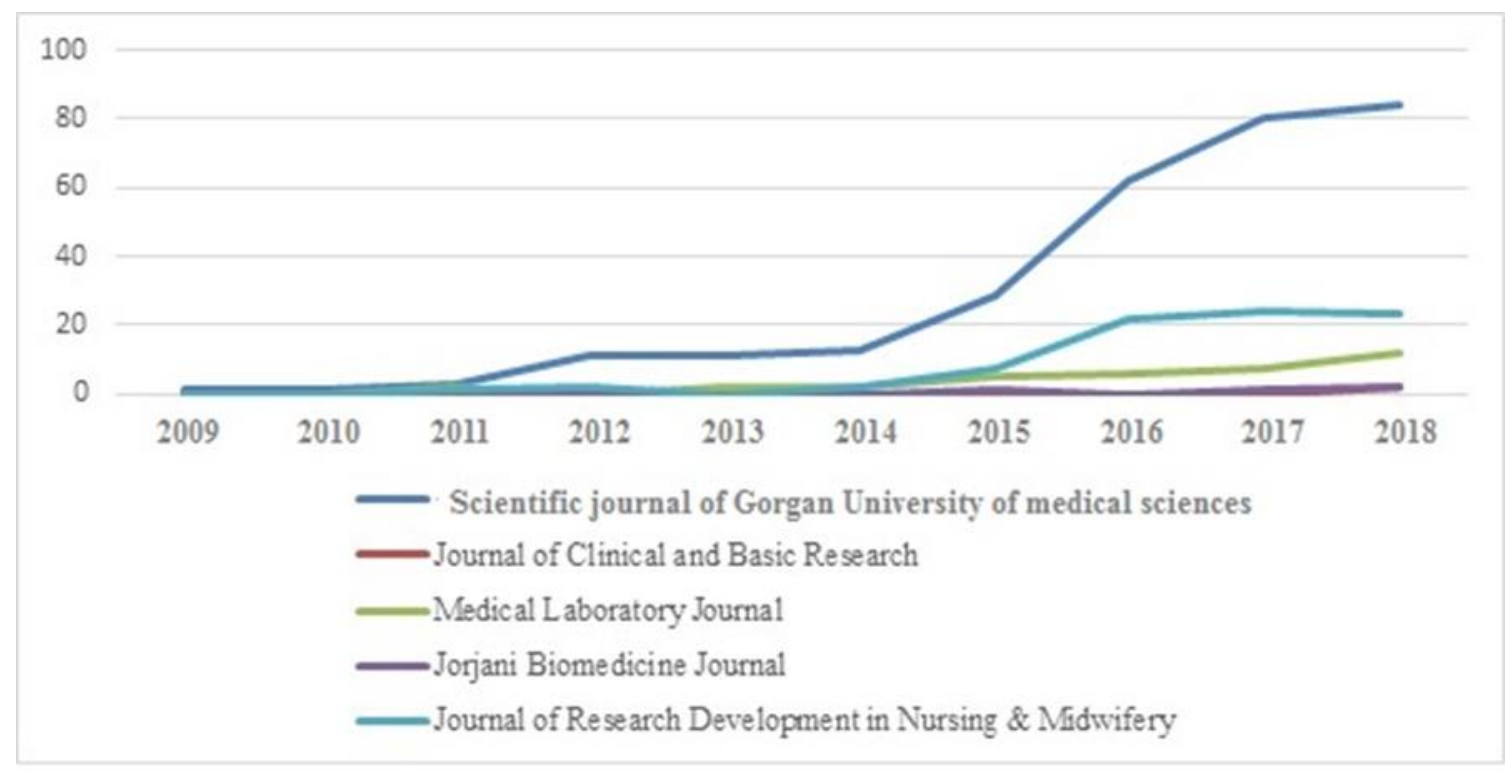

Figure 1. The citation process of articles in journals on Web of Science database

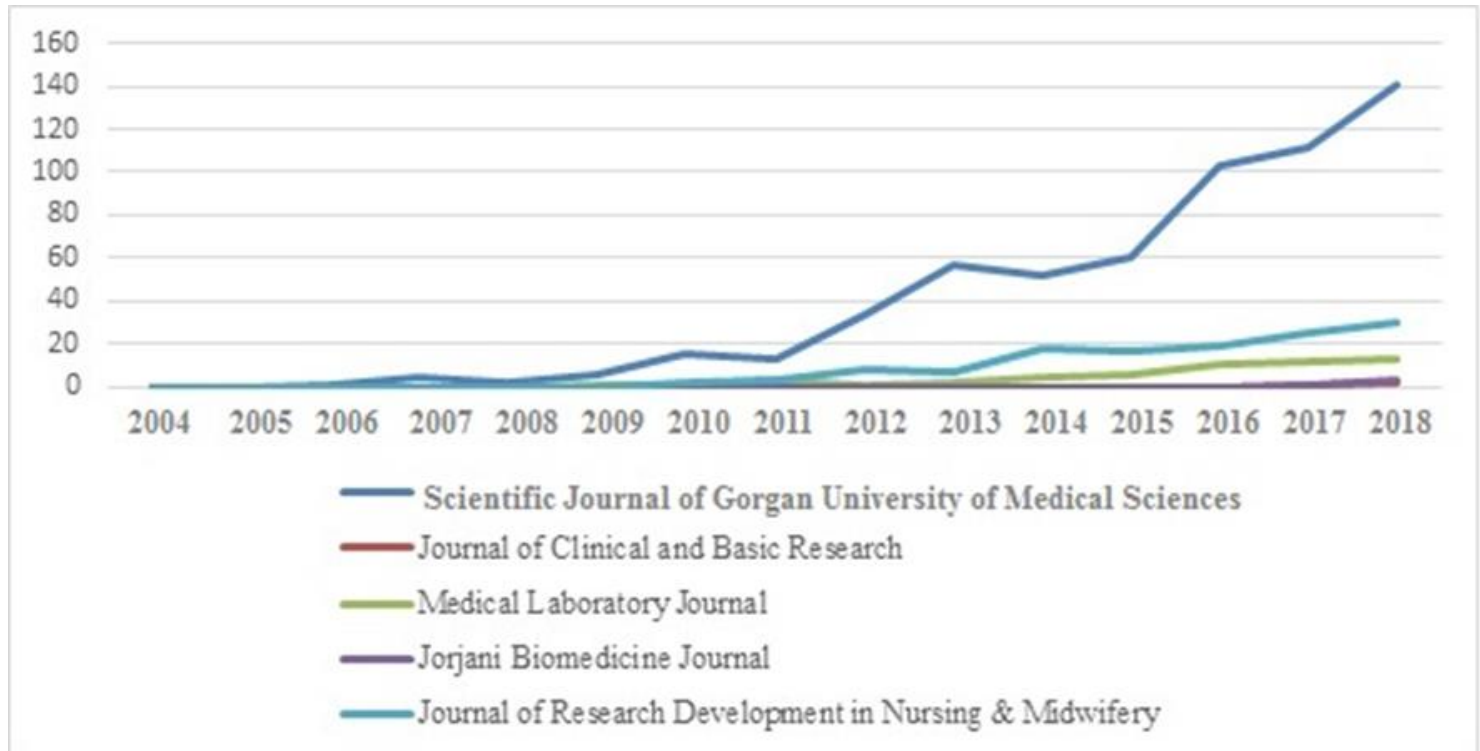

Figure 2. The citation process of articles in journals on Scopus database

\section{Discussion}

The observance of criteria of the National Medical Sciences Commission as the sole custodian of medical journals of Iran has a significant direct impact on the achievement of national standards and indirect impact internationally. Therefore, the observance of these cases was the main 
purpose of the present research. Based on the findings of the investigated components, only the Medical Laboratory Journal observed all cases; while the Journal of Development Research in Nursing \& Midwifery with compliances of only one condition had the least compliance with the requirements. In general, results of all studied journals indicated that the condition of "editor-inchief's activity in at most a journal as the editor" was met and the journals had favorable status in this regard, however, the condition, " at least half of the editorial staff should be outside the publisher institute", was only met by the Medical Laboratory Journal, indicating the need for special attention and change of editorial board policy in the other four journals. Two other conditions, "Being at least an associate professor for the editor-in-chief" and "At least 3 published articles in the last 3 years by editorial board", were not been met, only by the Journal of Research in Nursing \& Midwifery; hence, it should be taken into consideration in managerial policies of journal.

Given the participation and presence of international editorial board in the reviewed journals, the findings indicated that $37.14 \%$ of 105 editorial members in five journals had extra-organizational affiliation, and $8.57 \%$ were international authors. Due to the great importance of international editorial board members in journals for scientific databases and for indexing journals, the situation necessitates special attention to this component as well as to the collaboration of reviewed journals with international scientists and attraction of their participation. Similarly, another research presents cases such as the involvement of international scientists in editorial boards of journals as a strategy for quality improvement because the membership of international scientists in a bilateral relationship can potentially improve status of local journals and provide conditions in which scientists from developed countries benefit from studies in local communities of developing countries (11).

Based on the findings, the Journal of Clinical and Basic Research (JCBR) had the highest average of authors with an average of 4.1; while the articles of other journals had an average of 3.1. The situation was very similar to the results of another research on Iranian journals, so that an average of 4.43 authors in Palavered-e Salamat Journal, 3.6 authors in Koomesh Journal, and 3.03 authors in Health Information Management Journal contributed to authoring articles (3) (12, 13).

The findings also indicated that only 3 authors with organizational affiliation with Golestan University of Medical Sciences from the Jorjani Biomedicine Journal had collaborated with 
international authors, which in turn demonstrates the unfavorable conditions for international authors' participation in the publication of articles in studied journals. A similar study concluded the same result and considered the national and international support for scientists as the most important issues in promoting journals (11). However, findings suggested very favorable conditions for researchers outside the journal-publishing university. On average, 9.48 percent of authors of articles were affiliated with Golestan University of Medical Sciences and more than 90 percent of authors were from outside the journal-publishing university. Furthermore, more than 92 percent of first and corresponding authors of published articles had affiliations outside the journal-publishing university. Compared to other studies on other Iranian journals, the results indicated that journals of Golestan University of Medical Sciences were very different and became successful in attracting researchers from outside the journal-publishing organization. In Payavard-e Salamat Journal, which was published by Tehran University of Medical Sciences, more than half of authors were affiliated with Tehran University of Medical Sciences (3). It was similar to Koomesh and health information management journals in which most of articles were written by journal-publishing university $(12,13)$.

The status of citing articles of journal is another issue for indexing journals on international scientific databases. From this perspective, the research findings indicated that the Journal of Development Research in Nursing \& Midwifery with an average of 0.63 citations per article on Scopus citation database and 0.39 citations on Web of Science database was in desirable condition in terms of citing published articles, but in terms of counting number of citations, the findings indicated that "Scientific Journal of Gorgan University of Medical Sciences" with a total of 915 citations from two citation databases, Web of Science and Scopus, had the most indexing on these two databases. On average, articles of the journal received 0.56 of citations for Scopus and 0.37 citations for Web of Science. Similarly, another study considered the contextualization for indexing journals as a factor, which contributed to increasing visibility of articles, and noted the need to move towards providing journal indexing platforms in international indexes (11).

\section{Conclusion}

According to the results of the present study, journals of Golestan University of Medical Sciences needed revision and modification of structures, especially for editorial board such as 
being international, having outside-of-university affiliation, as well as presence of editorial board with great research activity and experience in order to strengthen its knowledge and compete with national and international scientific journals. Given the importance of decreasing the publishing process in attracting articles and audiences, the Journal of Development Research in Nursing \& Midwifery is suggested changing the publication sequence from bi-quarterly to quarterly or less.

\section{Acknowledgements}

The present article was derived from a research project that was approved by Golestan University of Medical Sciences (code 110823) and was confirmed by the ethics committee of Golestan University of Medical Sciences (Code of Ethics: IR.GOUMS.REC.1398.023).

\section{References}

1. Pashaaei zad H, Fadaie GH, Horri A. Study of the Publication Status of Scientific Journals in Iran. Research on Information Science and Public Libraries. 2011; 17(1):155-77.

2. Rezaeian M. The Problems of Local Journals in Health Domain and how to Overcome Them. JRUMS. 2011; 10(3):215-24. [Persian]

3. Azadeh F, Mirsaeed JG, Chashmyazdan MR. Survey on the Status of the Archive of Journals Approved by Commission for Accreditation and Improvement of Iranian Medical Journals. Hakim Research Journal. 2018; 20(4):226-33.

4. Ghazimirsaeid SJ, KolbadiNejad K, Momtazan M, Mohammadi M. Citation and content analysis of Journal of Payavard Salamat. J Mod Med Info Sci. 2015; 1(2):31-41. [Persian]

5. Farrokhnia M. The survey of Iranian English medical journals in some databases. JIPM 2011; 26(4):1068-88. [Persian]

6. Maghsoudi Daryeh R. Citation Analysis of PJCR Humanities Journals during 2003-2007. JIPM. 2011; 26(4):1139-58. [Persian]

7. Azadeh F, Ghazi Mirsaeid SJ, Gharib M, and Nabiolahi A. Survey on the Status of Indexing Latin Approved Medical Journals in Iran in Major Global Indexes. Payavard Salamat. 2017; 11(1):57-67. [Persian]

8. Repiso R, Castillo-Esparcia A, Torres-Salinas D. Altmetrics, alternative indicators for Web of Science Communication studies journals. Scientometrics. 2019; 119(2):941-58. [DOI: 10.1007/s11192-019-03070-7] 
9. The rules of the publication of medical science Commission of the Medical Journal of Iran; 2019.

10. Instructions and procedures for the approval of the principle: Commission of the Medical Journal of Iran; 2019.

11. Instructions on how to apply for scientific and research rank: Commission of the Medical Journal of Iran; 2019.

12. Rezaeian M. The Problems of Local Journals in Health Domain and how to Overcome Them Journal of Rafsanjan University of Medical Sciences. 2011; 10(3):215-24.

13. Marefat R, Saberi M, Abdolmajid A, Zoodranj M. A survey on collaboration rate of authors in presenting scientific papers in Koomesh journal during 1999-2010.koomesh. 2012; 13(3):27986. [Persian]

14. Ghahnaviyeh H, Movahedi F, Yarmohamadian MH, Ajami S. Content and Citation Analysis of Articles Published in the Journal of "Health Information Management". Health Information Management. 2011; 8(82-92). [Persian]

\section{Bibliographic information of this paper for citing:}

Mohammadi M, Mirkarimi M, Paranam Z, et al. A Study on the Status, Citation Analysis, and Altmetric Indices of Journals of Golestan University of Medical Sciences.

J Res Dev Nurs Midw, 2020; 17(1): 22-38.

Copyright (C) 2020, Masoud Mohammadi, Masoumeh Mirkarimi, Zohereh Paranam, Maryam Banisafar,Mohammad Yadegari, Marzieh Rezanejad, Mahin Tatari, Mohammad Mahboubi. 